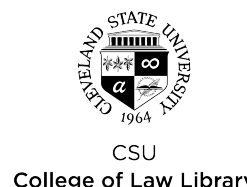

Cleveland State University

College of Law Library

\title{
EngagedScholarship@CSU
}

4-2009

\section{Do 'Off-Site' Adult Businesses Have Secondary Effects? Legal Doctrine, Social Theory, and Empirical Evidence}

\author{
Alan Weinstein \\ Cleveland State University, Cleveland-Marshall College of Law, a.weinstein@csuohio.edu \\ Richard D. McCleary \\ University of California - Irvine
}

Follow this and additional works at: https://engagedscholarship.csuohio.edu/fac_articles

Part of the Land Use Law Commons, State and Local Government Law Commons, and the Urban

Studies Commons

How does access to this work benefit you? Let us know!

\section{Original Citation}

Alan Weinstein and Richard D. McCleary, Do "Off-Site Adult Businesses Have Secondary Effects? Legal Doctrine, Social Theory, and Empirical Evidence, 31 Law and Policy 217 (2009)

This Article is brought to you for free and open access by the Faculty Scholarship at EngagedScholarship@CSU. It has been accepted for inclusion in Law Faculty Articles and Essays by an authorized administrator of EngagedScholarship@CSU. For more information, please contact research.services@law.csuohio.edu. 


\title{
Do "Off-Site" Adult Businesses Have Secondary Effects? Legal Doctrine, Social Theory, and Empirical Evidence*
}

\author{
Richard McCleary Alan C. Weinstein
}

\begin{abstract}
Recent federal court decisions appear to limit the ability of cities to mitigate the ambient crime risks associated with adult entertainment businesses. In one instance, a court has assumed that criminological theories do not apply to "off-site" adult businesses. After developing the legal doctrine of secondary effects, we demonstrate that the prevailing criminological theory applies to all adult business models. To corroborate the theory, we report the results of a before/after quasi-experiment for an off-site adult business. When an off-site adult business opens, ambient crime risk doubles compared to a control area. As theory predicts, moreover, ambient victimization risk is most acute in night-time hours. The theoretical development and empirical results have obvious implications for the evolving legal doctrine of secondary effects.
\end{abstract}

\section{INTRODUCTION}

Can a government, through zoning and licensing, regulate stores that sell sexually explicit material strictly for off-site use? As a matter of law, expressive activities that occur inside adult businesses enjoy a degree of First Amendment protection. ${ }^{1}$ The U.S. Supreme Court and the lower federal courts have ruled, nevertheless, that governments may regulate adult businesses so long as the regulations are aimed at mitigating the businesses' potential adverse "secondary effects," such as ambient noise, blight, and in particular, crime. ${ }^{2}$

To enact an adult business ordinance, a government must collect evidence to show that the businesses are associated with negative secondary effects. Many of the studies conducted by governments over the last three decades find that adult businesses do have significant secondary effects. Most of these studies assume that different types of adult businesses - cabarets, bookstores, arcades, etc. - have identical secondary effects, however. Whether warranted or not, this assumption has become legally problematic.

To illustrate the problem, suppose that each type of adult business has a unique "average" secondary effect. This implies that one of these different types would have the lowest effect of any adult business. The secondary effects of this type of business might conceivably be sufficiently de minimus as to fall below the Constitutional threshold where a government could regulate its operation. Alternatively, if the effect falls just above the threshold, the method of operation of that type of business might be "tweaked" to force its secondary effects below the threshold.

* Correspondence to mccleary@uci.edu or alan.weinstein@law.csuohio.edu. An earlier version of this paper was read at a panel of the American Society for Criminology, November $14^{\text {th }}, 2007$, Atlanta, GA. Marcus Felson, James W. Meeker, Wendy Regoeczi and anonymous referees commented on early drafts. 
What might this "bullet-proof" type of adult business look like? Common sense suggests that it would be a store that sells adult merchandise for off-site use. ${ }^{3}$ The typical customer drives to the store; parks; goes in; makes a purchase; comes out; and drives away. Except for the merchandise purchased, this routine activity is indistinguishable from the routine activities of convenience stores, dry cleaners, and libraries. Common sense argues then, that the secondary effects associated with off-site adult businesses are likely to be no larger than the analogous effects associated with convenience stores, dry cleaners, and libraries.

Adult book and video stores have made this common sense argument and some courts have found it persuasive. Like many common sense arguments, this one ignores theoretically relevant differences between adult and non-adult businesses. In fact, the routine activity theory of crime (Cohen and Felson, 1979; Felson and Cohen, 1980; Sherman, Gartin, and Buergner, 1989) predicts that virtually all types of adult businesses will have large, significant crimerelated secondary effects. The case study results reported here corroborate the theory for stores that sell adult merchandise strictly for off-site use. Before presenting the theory and evidence, we outline the evolution of the laws that Andrew (2000) calls the "secondary effects doctrine."

\section{EVOLUTION OF THE SECONDARY EFFECTS DOCTRINE}

Although the court decisions that motivate this essay were published in 2002 and 2003, both rest on an evolving body of law that begins thirty years earlier. In the late 1960s, Boston's city planners proposed to concentrate the city's adult businesses in a single small district. This proposal had two theoretical advantages. First, it would keep vice activity out of the city's other districts. Second, it would allow the police to focus resources on a small area, thereby reducing the risk of crimes associated with vice.

By the early 1970s, the failure of Boston's “combat zone" experiment was obvious (Skogan, 1992; Garnett, 2005). At about this time, Detroit consulted with social scientists and real estate experts on the question of whether adult businesses should be allowed to locate near other adult businesses. The experts agreed that dispersing adult businesses would mitigate their secondary effects. Relying on the experts' opinions, Detroit enacted an ordinance that set minimum distances between adult business sites. (American Mini-Theatres, Inc. v. Gribbs 1975 at 1018). Forced to relocate, several existing adult businesses challenged the Constitutionality of the Detroit ordinance. Borrowing from the vocabulary of antitrust cases, the U.S. Supreme Court ruled in Young v. American Mini-Theatres (1976) that governments could enact adult business ordinances so long as the ordinances were aimed at mitigating adverse secondary effects. By this test, the Court upheld the Detroit ordinance.

Although Young (1976) required that regulations be based on secondary effects evidence, it said nothing about the quantity or quality of the evidence. These questions were addressed ten years later in City of Renton v. Playtime Theatres, Inc. (1986). In the early 1980s, Renton, Washington enacted a zoning ordinance that in many respects resembled the ordinance challenged in Young. Since Renton had no adult businesses, it could not base its ordinance on local studies and so looked to a Washington Supreme Court opinion reviewing studies from nearby Seattle. (Northend Cinema, Inc. v. Seattle 1978). 
A year later, two theaters located in a prohibited district began to show X-rated films. In the ensuing challenge, the Supreme Court ruled that the ordinance complied with the Young (1976) standard in that its sole purpose was the mitigation of secondary effects. Further, the Court explicitly stated that a city need not conduct its own study of secondary effects or produce evidence of secondary effects in addition to that already available from other cities before enacting an ordinance regulating adult businesses, so long as the city believed that whatever studies or evidence it relied on were relevant to the problem the city was addressing. (Renton 1986 at 51-52). Renton (1986) thus legitimized the practice of basing a local ordinance on secondary effects studies from other communities. Renton (1986) also set a reliability threshold, albeit a low one, for the government's secondary effects evidence. The evidence must be "reasonably believed to be relevant." (Renton 1986 at 51-52).

The Supreme Court revisited this issue sixteen years later in its decision in City of Los Angeles v. Alameda Books, Inc. (2002). In 1977, Los Angeles had conducted a comprehensive secondary effects study that found, among other things, that concentrations of adult businesses were associated with high ambient crime rates. Based on this finding, Los Angeles enacted an ordinance requiring adult businesses to be separated by a minimum distance. The ordinance was amended in 1983 to prevent businesses from evading the minimum distance rule by merging into a single entity. Instead of requiring minimum distances between adult businesses, the amended ordinance required minimum distances between distinct adult entertainment activities. Adult businesses that combined on-site coin-operated video viewing booths with sales of videos for off-site use were prohibited. ${ }^{4}$ These multiple-activity businesses were forced to segregate their on-site and off-site activities.

In 1995, two multiple-activity businesses challenged the amended ordinance. Since the 1977 study said nothing about the secondary effects of combining multiple activities under one roof, they argued that Los Angeles had no evidence that multiple-activity businesses were associated with secondary effects. The federal District Court agreed and the $9^{\text {th }}$ Circuit Court of Appeals affirmed on the ground that because the 1977 Los Angeles study had not investigated the effects of multiple-activities under one roof, the evidence for the amended ordinance did not meet Renton's threshold of being reasonably relevant. (Alameda Books v. City of Los Angeles 2000). But the U.S. Supreme Court took a different view.

As often happens in First Amendment cases, the Supreme Court's decision did not produce a clear majority holding. Because the 1977 Los Angeles study had not investigated the effects of multiple-activities under one roof, the $9^{\text {th }}$ Circuit found that the evidence for the amended ordinance did not meet the Renton (1986) threshold. (Alameda Books 2000 at 727-28).

While acknowledging the limitations of the 1977 study, Justice O'Connor argued that Los Angeles could infer from its study that concentrations of adult activities would also be associated with secondary effects and, thus, that Los Angeles had complied with the evidentiary requirement of Renton (1986). ${ }^{5}$ Justice O'Connor then addressed what evidentiary standard a city would need to meet. After noting that in Renton (1986) the Court "held that a municipality may rely on any evidence that is 'reasonably believed to be relevant' for demonstrating a 
connection between speech and a substantial independent government interest," Justice O'Connor wrote:

This is not to say that a municipality can get away with shoddy data or reasoning. The municipality's evidence must fairly support the municipality's rationale for its ordinance. If plaintiffs fail to cast direct doubt on this rationale, either by demonstrating that the municipality's evidence does not support its rationale or by furnishing evidence that disputes the municipality's factual findings, the municipality meets the standard set forth in Renton. If plaintiffs succeed in casting doubt on a municipality's rationale in either manner, the burden shifts back to the municipality to supplement the record with evidence renewing support for a theory that justifies its ordinance. (City of Los Angeles 2002 at 438-39).

Applying this test to the case at hand, Justice O'Connor concluded that, given the early stage of the litigation, the city had complied with the evidentiary requirement of Renton (1986).

Justice Kennedy wrote a lengthy concurring opinion to express concern that "the plurality's application of Renton (1986) might constitute a subtle expansion" of what is permitted under that case. (City of Los Angeles 2002 at 425). ${ }^{6}$ In a dissenting opinion, Justice Souter, joined in part by Justice Breyer, argued that imposing stricter evidentiary standards on governments would guard against potential abuses and called for the Court to impose on government a requirement that it demonstrate empirically "that the [negative secondary] effects exist, that they are caused by the expressive activity subject to the zoning, and that the zoning can be expected either to ameliorate them or to enhance the capacity of the government to combat them (say, by concentrating them in one area), without suppressing the expressive activity itself." (City of Los Angeles 2002 at 452-53). ${ }^{7}$ In the final section of his dissent, which Justice Breyer did not join, Justice Souter applied this standard to the case at hand and argued that the city offered neither a rationale nor evidence to support the proposition that an adult bookstore combined with video booths would produce the claimed secondary effects. (City of Los Angeles 2002 at 461-64).

In the wake of Alameda Books (2002), adult businesses began to use the approach spelled out by the plurality to challenge ordinances. With one exception, most of these challenges have failed. If a regulation has a plausible rationale and if it is supported by at least some evidence, the courts continue to show substantial deference to legislatures. See, e.g., (G.M.Enterprises, Inc. v. Town of St. Joseph, WI 2003; Giovani Carandola, Ltd. v. Fox 2005; Abilene Retail \#30, Inc. v. Board of Commissioners of Dickinson Cty. 2005). ${ }^{8}$

Challenges to government regulations of off-site adult businesses are an exception to this rule. In Encore Videos, Inc. v. City of San Antonio (2003), an ordinance classified off-site book and video stores as adult entertainment businesses if their inventories included 20 percent adult material. Citing Alameda Books (2002), an off-site book store challenged the ordinance's rationale and underlying evidence. Agreeing, the $5^{\text {th }}$ Circuit found that San Antonio had relied on studies that either excluded off-site adult businesses or, otherwise, had not distinguished between the effects of on-site and off-site adult businesses. In the Court's view, moreover, the 
city's rationale for ignoring the differences between on-site and off-site businesses was weak.

Off-site businesses differ from on-site ones, because it is only reasonable to assume that the former are less likely to create harmful secondary effects because of the fact that consumers of pornography are not as likely to linger in the area and engage in public alcohol consumption and other undesirable activities. (Encore Videos at 294-95).

Other factors influenced the decision, of course, and a recent $5^{\text {th }}$ Circuit decision, to be discussed shortly, clarifies Encore Videos (2003). For present purposes, however, we end with the Court's theory. While the theory is compelling from a commonsense perspective, it ignores theoretically relevant characteristics of off-site adult businesses.

\section{THE ROUTINE ACTIVITY THEORY OF CRIME HOT SPOTS}

The prevailing criminological theory of secondary effects is derived from a special case of the routine activity theory of crime (Cohen and Felson, 1979; Felson and Cohen, 1980; Clarke, 1983; Felson, 1998). Applied to secondary effects, the theory holds that the routine activity at adult business sites attracts predators, generating a "hotspot of predatory crime" (Sherman, Gartin, and Buerger, 1989; Brantingham and Brantingham, 1981, 1993).

Applied to crime hotspots, the routine activity theory assumes that a pool of offenders moves freely from site to site, stopping to prey when a relatively attractive site is discovered. The relative attractiveness of a site is proportional to the number of targets, weighted by their value, and inversely proportional to the level of police presence at the site. Sites with relatively many high-value targets and relatively low police presence attract relatively many predators.

Limiting the routine activity theory to crime hot spots allows for two simplifications of the original general theory of Cohen and Felson (1979; Felson and Cohen, 1980). First, the original theory's more general "capable guardians" factor can be reduced to police presence at the site. Second, the original theory's more general "suitability" factor, which determines the relative risk of a target, can be reduced to the value, in the predator's estimation, of the targets at a site. Both simplifications reflect the characteristics of the expected offenders.

The offenders who are attracted to adult business sites lack legitimate means of livelihood and devote substantial time to illegitimate activities. By Sutherland's (1937) definition, they are "professional thieves." Otherwise, they are a heterogeneous group. Some are vice purveyors who dabble in crime; others are criminals who use the promise of vice to lure and lull their victims. Despite their heterogeneity, these predators share a rational decision-making calculus that draws them to adult business sites.

The connection between vice and predatory crime has been a popular plot device for at least 250 years. John Gay's (1728) Beggar's Opera, for example, centers on the relationship between MacHeath, a predatory criminal, and the vice ring composed of Peachum, Lucy, and Jenny. This popular view is reinforced by the empirical literature on criminal lifestyles and 
OFF-SiTE Adult BuSINESSES - 6

thought processes. The earliest and best-known study (Shaw, 1930; Snodgrass, 1982) describes

"Stanley," a delinquent who lives with a prostitute and preys on her clients.

Criminological thinking on the connection between vice and predatory crime has changed little in the 75 years since Shaw's Jack-Roller (Felson, 2006; Potter, 1989). To document the rational choices of predatory criminals, Wright and Decker (1997) interviewed 86 active armed robbers. Asked to describe a perfect victim, all mentioned victims involved in vice, either as sellers or buyers. Three of the armed robbers worked as prostitutes:

From their perspective, the ideal robbery target was a married man in search of an illicit sexual adventure; he would be disinclined to make a police report for fear of exposing his own deviance (p. 69).

The rational calculus described by these prostitute-robbers echoes the descriptions of other predators (see, e.g., Bennett and Wright, 1984; Feeney, 1986; Fleisher, 1995; Katz, 1988, 1991; Shover, 1998).

Like tourist attractions (Dimanche and Lepetic, 1999; Danner, 2003) and sporting events (Corcoran, Wilson and Ware, 2003; Westcott, 2006), adult business sites attract targets from wide catchment areas. Compared to the targets attracted to these other hotspots, however, adult business patrons are disproportionately male, open to vice overtures, and carry cash. When victimized, moreover, adult business patrons are reluctant to involve the police. They are "perfect" victims, from the rational predator's perspective.

Given a choice among equally lucrative sites, predators prefer sites with low levels of police presence (Sherman and Weisburd, 1995). In the original statement of the routine activity theory (Cohen and Felson, 1979; Felson and Cohen, 1980), the pool of "capable guardians" included not only the police but, also, the targets themselves and any potential witnesses. Given the stigma associated with adult businesses, however, customers may be reluctant to have their presence at the site documented in police records. The level of guardianship at an adult business site then is proportional to the level of physical (e.g., motor or foot patrols) or virtual (e.g., security cameras) police presence.

The relative effectiveness of a fixed level of police presence can be affected by broadly defined environmental factors, of course. Because conventional police patrolling is less effective in darkness, for example, ambient victimization risk rises after dark (Coupe and Blake, 2006). Architectural structures that obscure vision can have a similar effect but outdoor lighting can mitigate the risk (Farrington and Welsh, 2002). Because rural areas have fewer police resources (Thurman and McGarrell, 1997; Weisheit, Falcone, and Wells, 1999), rational predators may view rural adult business sites as more attractive (McCleary, 2008).

In theory, any type of adult business that attracts high-value targets will generate an ambient public safety hazard. The theory allows for qualitative differences nevertheless. Some differences arise from idiosyncratic opportunity structures associated with a particular type of adult business. In this instance, for example, the video viewing booths that distinguish on-site 
and off-site adult bookstores create opportunities for victimless vice crimes (Sundholm, 1973; Tewksbury, 1993; Weatherford, 1986). To the extent that on-site and off-site adult bookstores attract high-value targets from wide catchment areas, both business types are expected to attract predators to their neighborhoods, thereby generating ambient victimization risk. The case study data presented here corroborate this theoretical expectation.

\section{DR. JOHN'S: A CASE STUDY}

Adult businesses are nothing new to Sioux City, Iowa. Two adult businesses had operated without incident in the city's older downtown area for decades. Although both businesses sold sexually explicit DVDs for off-site use, most of their revenue came from coinoperated viewing booths. Nevertheless, strictly speaking, both belonged to the adult business model that Justice Souter characterized as the "commercially natural, if not universal" model. (City of Los Angeles 2002). In terms of "look and feel," the two businesses were indistinguishable from adult businesses in larger cities.

In March, 2004, a third adult business, Dr. John's, opened in Sioux City. Unlike the two existing businesses, $D r$. John's had no viewing booths. It was located in a newer area of the city and lacked the garish appearance often associated with adult businesses generally and, in particular, with Sioux City's two existing adult businesses. During subsequent litigation, the trial judge commented on this fact:

[T] he first impression of the store is a far cry from the first image that most people would likely have of an "adult book store" or "sex shop." There is nothing seedy about the neighborhood, store building, or store front. In fact, from a quick drive-by, one would likely assume that the business was a rather upscale retail store for women's clothing and accessories. There are no "adult" signs or banners proclaiming "peep shows," "live entertainment booths," "XXX movies," "live models," "adult massage," or any of the other tasteless come-ons all too familiar from adult entertainment stores that exist in virtually every American city of any size and which one may find scattered along interstates and highways even in rural America. (Dr. John's, Inc. v. City of Sioux City, IA 2005 at 1103).

The trial judge's drive-by impression may overstate the point. Few passers-by would mistake $D r$. John's for anything other than what it was.

Regardless of its look and feel Dr. John's was located in a prohibited zone. When Sioux City attempted to enforce its zoning code, Dr. John's sued, arguing that off-site adult businesses lacked the typical crime-related secondary effects associated with adult businesses. To counter this argument, Sioux City produced police reports of incidents occurring within 500 feet of $D r$. John's during the four years between January $1^{\text {st }}, 2002$ and December $31^{\text {st }}, 2005$. For purposes of quasi-experimental control, reports of incidents occurring within 500 feet of a nearby motel were also retrieved.

Table 1 breaks the incidents down by broad categories for 793 days before and 668 days 
after Dr. John's opened. In the Dr. John's circle, the annual crime rate rose from 7.8 to 22.4 incidents per year, an increase of approximately 190 percent. Crime in the control circle rose as well, from 20.3 to 25.1 incidents per year, a more modest increase of approximately 25 percent. Assuming that plausible alternative hypotheses can be ruled out, a crude comparison of rates suggests that Dr. John's poses an ambient victimization risk.

Table 1- Crime Incidents Before and After the Opening of Dr. John's

\begin{tabular}{lcccc} 
& \multicolumn{2}{c}{ Dr. John's } & \multicolumn{2}{c}{ Control } \\
& Before & After & Before & After \\
Property & 10 & 20 & 21 & 25 \\
$\begin{array}{l}\text { Personal } \\
\text { Other }\end{array}$ & 1 & 3 & 8 & 5 \\
Total & 6 & 18 & 15 & 16 \\
\hline
\end{tabular}

Null Hypothesis. The most obvious alternative hypothesis is that the before/after effect is due to chance. To test this hypothesis, we take advantage of the fact that crime incidents in the two circles are not different than Poisson (Haight, 1967: 94-95). Under a Poisson hypothesis, the after/before odds for the Dr. John's and control circles, reported in Table 2, are distributed as unit-mean log-Normal variables (Bishop, Fienberg, and Holland, 1975: 315-17). The ratio of the two odds, also distributed as unit-mean log-Normal, is the maximum-likelihood estimate of the before/after change. In this instance, the estimated odds ratio $(17 / 41 \mathrm{x} 44 / 46 \approx 2.31)$ implies that ambient crime rose by 131 percent after the opening of Dr. John's. Since estimates of this size or larger occur by chance with probability smaller than 0.01 , the null hypothesis is rejected.

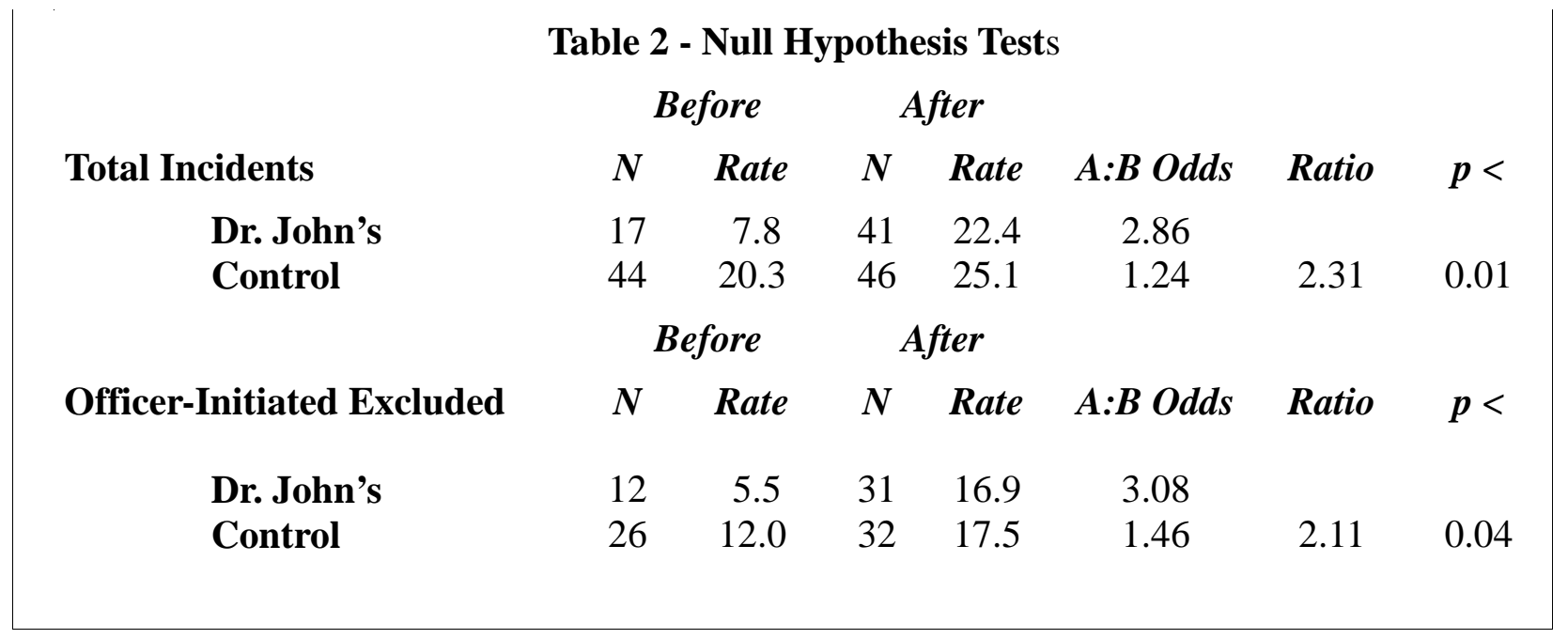

Internal Validity. Another set of alternative hypotheses involve uncontrolled threats to internal validity. The quasi-experimental design summarized in Table 1 is a variation of the 
OFF-Site Adult BuSINESSES - 9

Campbell and Stanley (1963: 55) "multiple interrupted time series quasi-experiment." It is "the best of the more feasible designs," in their opinion (Campbell and Stanley, 1963: 57; see also, Cook and Campbell, 1979: 214-218; Shadish, Cook, and Campbell, 2002: 206). All three primary authorities cite history, maturation, and instrumentation as plausible threats to internal validity. The control circle contrast makes these threats implausible in principle. If the $D r$. John's and control circles have significantly different crime risk factors, however, the quasiexperimental contrast fails.

Campbell and Stanley (1966, pp. 55-57) analyze the failed quasi-experimental contrast as a selection-interaction threat. Because selection-interaction is defined by the logical conjunction of selection and, in this instance, history, maturation, or instrumentation, selection-interaction is ruled out by ruling out selection; or by ruling out history, maturation, and instrumentation. We use both arguments to rule out the plausible alternative explanations based on uncontrolled threats to internal validity.

Selection. Ambient crime risk factors in the Dr. John's and control circles seem roughly comparable. Because the two circles are tangent, for example, face the same thoroughfare, and have identical pedestrian accesses, their traffic flows are identical. Because the two circles have roughly the same numbers and types of businesses, they have roughly comparable opportunities for commercial crime. The circles are in the same Census blocks, municipal zone, and postal (zip) code.

The crime rates in Table 2 suggest one apparent difference, nevertheless. Over the 793day pre-intervention period, the crime rate in the control circle is approximately 2.5 times that of the Dr. John's circle. Much of this difference is due to the fact that the control circle is centered on a motel and that the local police department uses a National Incident Based Reporting (NIBRS) coding protocol. ' If the Uniform Crime Reporting (UCR) "hotel" and "hierarchical" coding rules were applied to these data, the difference in crime rates would be reduced by half (Rantala and Edwards, 2000; James and Council, 2008). ${ }^{10}$ Since the NIBRS protocol is used in both the pre- and post-intervention segments, of course, its effect is cancelled in the before/after ratio. Otherwise, the control circle appears roughly comparable to the Dr. John's circle in all theoretically relevant respects.

Although a selection-interaction threat cannot be ruled out categorically, it does not seem to be wholly plausible. When plausibility of the conjoined threats of history, maturation, and/or instrumentation are considered, moreover, a selection-interaction seem wholly implausible. We begin with the least plausible of the three conjoined threats.

Maturation. If a times series is a realization of a non-stationary process, any arbitrary test of a before/after null hypothesis is biased in favor of rejection. Since homogeneous Poisson processes are stationary (Kingman, 1993: 9-10), the maturation hypothesis can be tested through a Poisson goodness-of-fit test. Since a Kolomogorov-Smirnov test statistic (Kendall and Stuart, 1979: 476-481) for the daily time series $(Z=0.14)$ lies within the 95 percent confidence interval ( $p<0.89)$, the Poisson hypothesis cannot be rejected. Accordingly, the maturation hypothesis is implausible. 
History. To assess the threat of history, public records and local media were searched for the period of 120 days before and 120 days after the opening of Dr. John's. The search turned up no potentially disruptive events within 1,500 feet of either site during that period. History too is implausible.

Instrumentation. Instrumentation threats arise in crime rate time series when an intervention affects the manner in which crimes incidents are recorded (McCleary, Erven, and Nienstedt, 1982). If the opening of an adult business like Dr. John's leads to heightened police surveillance, for example, the probability of discovering and recording latent incidents may rise. ${ }^{11}$ Whereas this explanation might be plausible for crime incidents discovered by police patrols, however, it is implausible for crimes reported to the police by victims or witnesses.

This suggests a straightforward test of the instrumentation hypothesis. Based on their independent reading of crime incident narrative reports, graduate research assistants separated the incidents into incidents initiated by a complaining victim or witness and incidents initiated by patrol officers. As reported in Table 2, excluding officer-initiated crime incidents leads to the same conclusion. The null hypothesis is rejected with 95 percent confidence, rendering the instrumentation hypothesis implausible.

\begin{tabular}{|c|c|c|c|c|}
\hline \multicolumn{5}{|c|}{ Table 3 - Crime Incidents by Time of Occurrence } \\
\hline & \multicolumn{2}{|c|}{ Dr. John's } & \multicolumn{2}{|c|}{ Control } \\
\hline & Before & After & Before & After \\
\hline $8 P M-3: 59 A M$ & 3 & 21 & 12 & 13 \\
\hline $4 A M-7: 59 P M$ & 14 & 20 & 32 & 33 \\
\hline \multirow[t]{2}{*}{ Total } & 17 & 41 & 44 & 46 \\
\hline & \multicolumn{4}{|c|}{ Odds Ratio $=4.66 ; \quad t$-Statistic $=1.88$} \\
\hline
\end{tabular}

In addition to hypothesis tests for specific threats to internal validity, the plausibility of any alternative hypothesis rests on the coherence of the observed effect (Shadish, Cook, and Campbell, 2002: 35-36). Table 3 reports auxiliary data that indirectly corroborate a nominal interpretation of the before/after effect. The before/after effect is most pronounced during the eight-hour overnight shift. Because 24-hour businesses had operated in both circles without interruption since 2002, the abrupt increase in nighttime risk cannot be attributed to the mere onset of late-night and early-morning commerce but, rather, must be attributed to the adult nature of the new commercial activity.

\section{Discussion}

Readers who are unfamiliar with Poisson time series might be tempted to discount the statistical significance levels reported in Tables 1-3. The statistical significance of a Poisson 
OFF-SiTE AdULT BUSINESSES - 11

time series effect is determined not by the number of non-zero observations, however, but by the length of the series. Time series of $\mathrm{N}=1,461$ daily observations are sufficiently long to detect effects considerably smaller than those reported.

Although the common threats to internal validity cannot be ruled out categorically, they do not seem plausible in light of the available auxiliary data. Questions of generality remain, of course. That is the nature of case study evidence. Nevertheless, in light of the strong underlying theory and the coherent pattern of effects, it is reasonable to think that the findings apply to offsite adult businesses generally.

The routine activity theory of hot spots holds that people who carry cash and who are reluctant to report crimes are at risk of predation. Adult business customers are not alone in that respect. Drug dealers (Topalli, Wright and Fornango, 2002) and illegal immigrants (Davis, Erez, and Avitabile, 2001) are vulnerable to predation for similar reasons. When vulnerable targets are attracted to a site, their presence attracts predators with predictable consequences: ambient crime risk. Adult business sites are not unique in that respect. Currency exchanges are notorious hot spots because illegal immigrants who cash checks at the site are robbed as they walk home (Barr, 2004). Pedestrians in downtown commercial districts do not carry cash and are not reluctant to report crimes; and they have relatively low robbery risks (Wright and Decker, 1997).

The coherent pattern of effects reinforces the theory. The routine activity theory holds that crime rates rise and fall across a 24-hour day in response to the diurnal routine activity cycle, for example. Crime rates are lower at night because businesses are closed and people are safely asleep in their homes; fewer targets are available for predation. When targets are at risk around the clock, however, the risk is most acute in hours of darkness (Van Koppen and Jansen, 1999; Coupe and Blake, 2006). The corroborating post-intervention diurnal cycle (Table 3) makes the straightforward generalization more credible.

In contrast to the relevant criminological theory, the common sense theory of secondary effects predicts that off-site adult bookstores pose relatively small ambient public safety hazards. This prediction rests on the assumption that an "average" customer drives up to the store, parks, runs in, makes a purchase, runs out, and drives off. Because the "average" customer spends very little time in and around the store, the neighborhood will have few (if any) vulnerable targets to attract predators. Absent both targets and predators, common sense argues the crime-related secondary effects of off-site adult bookstores will be smaller than the analogous effects of on-site adult businesses.

Although the assumed "average" behavior of off-site adult business customers may be consistent with common sense, it is inconsistent with the data. In an ethnographic study of an off-site adult business, Hefley (2007) reports that patrons spend significant periods of time in the immediate vicinity of the site. Some wait outside until the business is empty. Others "case" the business on multiple occasions before deciding to enter. Some patrons park their cars a block or more away and walk to the store. These "average" behaviors attract predators to the site, creating the ambient public safety hazard predicted by the routine activity theory. 
OFF-SITE AdULT BUSINESSES - 12

Like the formal scientific theories that they precede, common sense theories evolve in light of experience (Popper, 1979: 32-105). An ambiguous passage in the Encore Videos (2002) decision left the impression that the $5^{\text {th }}$ Circuit had endorsed an interpretation of criminological theory favoring the plaintiffs. Four years later, however, in $\mathrm{H}$ and A Land Corp. v. City of Kennedale (2007), the Court revisited the issue. In Encore Videos (2002), the $5^{\text {th }}$ Circuit struck down portions of a San Antonio ordinance that dealt with off-site adult bookstores because the factual predicate of the ordinance included no secondary effects studies of off-site stores. The factual predicate of the ordinance challenged in H and A Land Corp (2007), in contrast, included at least two studies of the secondary effects of off-site adult businesses. The $5^{\text {th }}$ Circuit panel upheld the ordinance on that basis:

This case differs from Encore Videos because Kennedale, unlike San Antonio, offers evidence that purports to show a connection between purely off-site businesses, or "bookstores," and harmful secondary effects. (H and A Land Corp 2007 at 339)

The $5^{\text {th }}$ Circuit panel, including one member who had participated in Encore Videos, took the unusual step of retracting the ambiguous passage that seemed to endorse an interpretation of criminological theory favoring plaintiffs. This clarification proved prescient. One week later, a customer who had parked several hundred feet away from one of the plaintiff's off-site stores was confronted by an armed robber and seriously wounded (Bourgeois, 2007). The facts of this incident are consistent the data and theory. ${ }^{12}$

The secondary effects studies relied upon in H and A Land Corp. (2007), as well as the case study findings reported here, corroborate the criminological theory of routine activities. In turn, these findings corroborate the findings and experiences of urban planners (Burr, 1998; Ford and Beveridge, 2004; Papayanis, 2000; Ryder, 2004). The emerging picture of the problems associated adult businesses is convincing. Governments have the ethical dilemma of balancing the mitigation of secondary effects and the First Amendment rights of citizens.

\section{REFERENCES}

Andrew, Christopher J. (2002) "The Secondary Effects Doctrine: The Historical Development, Current Application, and Potential Mischaracterization of an Elusive Judicial Precedent," Rutgers Law Review 54: 1175-1220.

Barr, Michael S. (2004) Banking the Poor: Policies to Bring Low-Income Americans into the Financial Mainstream, Working Paper 48. Ann Arbor. John M. Olin Center for Law and Economics, University of Michigan Law School.

Bennett, Trevor and Richard Wright (1984) Burglars on Burglary: Prevention and the Offender. London: Gower.

Bishop, Yvonne M.M., Stephen E. Fienberg, and Paul W. Holland (1975) Discrete Multivariate Analysis: Theory and Practice. Cambridge MA: MIT Press.

Bourgeois, P. (2007) "Man shot outside video store in Kennedale," Fort Worth Star-Telegram, March $2^{\text {nd }}$, page B4.

Brantingham, Paul L. and Patricia J. Brantingham (1981) "Notes on the Geometry of Crime." In 
OFF-SiTE AdULT BuSINESSES - 13

Environmental criminology, edited by Paul L. Brantingham and Patricia J. Brantingham. Thousand Oaks, CA: Sage.

Brantingham, Paul L. and Patricia J. Brantingham (1993) "Nodes, Paths and Edges:

Considerations on Environmental Criminology," Journal of Environmental Psychology, 13:3-28.

Burr, Tom (1998) 'Sleazy City: ‘42nd Street Structures' and Some Qualities of Life,” October Magazine 85: 90-105.

Campbell, Donald T. and Julian C. Stanley (1966) Experimental and Quasi-Experimental Designs for Research. Chicago: Rand-McNally.

Clarke, Ronald V. (1983) "Situational Crime Prevention: Its Theoretical Basis and Practical Scope." In Crime and Justice: Annual Review of Research edited by Michael Tonry and Norval Morris. Chicago: University of Chicago Press.

Cohen, Lawrence E. and Marcus Felson (1979) "Social Change and Crime Rate Trends: A Routine Activity Approach," American Sociological Review 44:588-608.

Cook, Thomas D. and Donald T. Campbell (1979) Quasi-Experimentation: Design and Analysis Issues for Field Settings. Chicago: Houghton-Mifflin.

Coupe, Timothy and Lawrence Blake (2006) "Daylight and Darkness Targeting Strategies and the Risks of Being Seen at Residential Burglaries," Criminology 44:431-464.

Danner, Terry A. (2003) "Violent Times: A Case Study of the Ybor City Historic District," Criminal Justice Policy Review 14:3-29.

Davis, Robert C., Edna Erez, and Nancy Avitabile (2001) “Access to Justice for Immigrants Who Are Victimized: The Perspectives of Police and Prosecutors," Criminal Justice Policy Review 12:183-196.

Dimanche, Frederic and Allena Lepetic (1999) "New Orleans Tourism and Crime: A Case Study," Journal of Travel Research 38:19-23.

Farrington, David P. and Brandon C. Welsh (2002) Effects of Improved Street Lighting on Crime: A Systematic Evaluation. London: Home Office Research Development and Statistics Directorate.

Feeney, Floyd (1986) "Robbers as Decision-Makers." In The Reasoning Criminal: Rational Choice Perspectives on Offending edited by David Cornish and Ronald V. Clarke. New York: Springer-Verlag.

Felson, Marcus (1996) Crime and Nature. Thousand Oaks, CA: Pine Forge Press.

Felson, Marcus (1998) Crime and Everyday Life, Second Edition. Thousand Oaks, CA: Pine Forge Press.

Felson, Marcus and Lawrence E. Cohen (1980) "Human Ecology and Crime: A Routine Activities Approach," Human Ecology 8:389-406.

Fleisher, Mark S. (1995) Beggars and Thieves: Lives of Urban Street Criminals. Madison: University of Wisconsin Press.

Ford, Julie M. and Andrew A. Beveridge (2004) “"Bad Neighborhoods,' Fast Food, 'Sleazy Businesses,' and Drug Dealers: Relations Between the Locations of Licit and Illicit Businesses in the Urban Environment," Journal of Drug Issues 34:51-76.

Garofalo, James and David Clark (1992) "Guardianship and Residential Burglary," Justice Quarterly 9:443-463.

Garnett, Nicole Stelle (2005) “Relocating Disorder,” Virginia Law Review 91:1076-1134.

Gay, John (2006[1728]) The Beggar's Opera. New York: Hard Press Editions. 
OFF-SiTE AdULT BUSINESSES - 14

Hefley, Kristen (2007) "Stigma Management of Male and Female Customers to a Non-Urban Adult Novelty Store," Deviant Behavior 28:79-109.

James, Nathan and Logan Richard Council (2008) How Crime in the United States is Measured. Document RL34309. Washington, D.C.: Congressional Research Service.

Katz, Jack (1988) Seductions of Crime: Moral and Sensual Attractions in Doing Evil. New York: Basic Books.

Katz, Jack (1991) "The Motivation of the Persistent Robber." In Crime and Justice: A Review of Research edited by Michael Tonry. Chicago: University of Chicago Press.

Kendall, Maurice G. and Alan Stuart (1979) The Advanced Theory of Statistics, Volume 2, $4^{\text {th }}$ Ed. London: Charles Griffin and Company.

Kingman, J.F.C. (1993) Poisson Processes. London: Clarendon Press.

Koper, Christopher S. (1995) "Just Enough Police Presence: Reducing Crime and Disorderly Behavior by Optimizing Patrol Time in Crime Hot Spots," Justice Quarterly 12:649-672.

McCleary, Richard (2008) "Rural Hotspots: The Case of Adult Businesses," Criminal Justice Policy Review 19:153-163.

McCleary, Richard, James M. Erven and Barbara C. Nienstedt (1982) "Uniform Crime Reports as Organizational Outcomes: Three Time Series Experiments," Social Problems 29:361372.

Musgrave, Alan (1993) Common Sense, Science, and Scepticism: A Historical Introduction to the Theory of Knowledge. Cambridge: Cambridge University Press.

Newman, Oscar (1973) Defensible Space: Crime Prevention Through Urban Design. New York: MacMillan.

Papayanis, M.A. (2000) "Sex and the Revanchist City: Zoning Out Pornography in New York," Environment and Planning 18: 341-353.

Paul, Bryant, Daniel Linz and Bradley J. Shafer (2001) "Government Regulation of 'Adult' Businesses through Zoning and Anti-Nudity Ordinances: De-Bunking the Legal Myth of Negative Secondary Effects," Communication Law and Policy 6:355-391.

Popper, Karl R. (1979) Objective Knowledge: An Evolutionary Approach, Revised Edition. London: Clarendon Press.

Potter, Gary W. (1989) “The Retail Pornography Industry and the Organization of Vice," Deviant Behavior 10:233-251.

Rantala, Ramona R. and Thomas J. Edwards (2000) Effects of NIBRS on Crime Statistics. Washington, D.C.: U.S. Department of Justice, Federal Bureau of Investigation.

Ryder, Andrew (2004) "The Changing Nature of Adult Entertainment Districts: Between a Rock and a Hard Place or Going from Strength to Strength?" Urban Studies 41:1659-1686.

Shadish,William R., Thomas D. Cook, and Donald T. Campbell (2002) Quasi-Experimental Designs for Generalized Causal Inference. Chicago: Houghton-Mifflin.

Shaw, Clifford R. (1966[1930]) The Jack-Roller: A Delinquent Boy's Own Story. Chicago: University of Chicago Press.

Sherman, Lawrence W., Patrick R. Gartin and Michael E. Buerger (1989) "Hot Spots of Predatory Crime: Routine Activities and the Criminology of Place," Criminology 27:2755.

Sherman, Lawrence W. and David Weisburd (1995) "General Deterrent Effects of Police Patrol in Crime Hot Spots: A Randomized Controlled Trial,” Justice Quarterly 12:626-648.

Shover, Neal (1996) Great Pretenders: Pursuits and Careers of Persistent Thieves. Boulder, 
CO: Westview.

Skogan, Wesley G. (1992) Disorder and Decline: Crime and the Spiral of Decay in American Neighborhoods. Oakland: University of California Press.

Snodgrass, Jon (1982). The Jack-Roller at Seventy. Lexington, MA: Lexington Books.

Sundholm, Charles A. (1973) "The Pornographic Arcade: Ethnographic Notes on Moral Men in Immoral Places," Urban Life and Culture 2:85-104.

Sutherland, Edwin H. (1937) The Professional Thief. Chicago: University of Chicago Press.

Thurman, Quinn and Edmund G. McGarrell (1997) Community Policing in a Rural Setting. Cincinnati, $\mathrm{OH}$ : Anderson.

Topalli, Volkan, Richard Wright and Robert Fornango (2002) "Drug Dealers, Robbery and Retaliation: Vulnerability, Deterrence and the Contagion of Violence," British Journal of Criminology 42:337-351.

Tewksbury, Richard (1993) "Peepshows and 'Perverts': Men and Masculinity in an Adult Bookstore," Journal of Men's Studies 2:53-67.

Van Koppen, Peter J. and Robert W.J. Jansen (1999) "The Time to Rob: Variations in Time of Number of Commercial Robberies," Journal of Research in Crime and Delinquency 36:7-29.

Weatherford, Jack McIver (1986) Porn Row. New York: Arbor House.

Weisheit, Ralph A., Falcone, David N., and L. Edward Wells (1999) Crime and Policing in Rural and Small-Town America, $2^{\text {nd }}$ Ed. Prospect Heights, IL: Waveland Press.

Wright, Richard T. and Scott H. Decker (1997) Armed Robbers in Action: Stickups and Street Culture. Boston: Northeastern University Press.

\section{Cases Cited}

Abilene Retail \#30, Inc. v. Board of Commissioners of Dickinson County, 402 F.Supp.2d 1285 (2005)

Alameda Books, Inc. v. City of Los Angeles, 222 F.3d 719 (9 ${ }^{\text {th }}$ Cir. 2000).

American Mini-Theatres, Inc. v. Gribbs, 518 F.2d 1014 (1975) at 1018.

City of Erie v. Paps, A.M., 529 U.S. 277 (2000).

City of Los Angeles v. Alameda Books, Inc., 535 U.S. 425 (2002).

City of Renton v. Playtime Theatres, Inc., 475 U.S. 41 (1986).

Doctor John's, Inc. v. City of Sioux City, IA., 389 F.Supp.2d 1096, 1103 (N.D. Iowa 2005)

Encore Videos, Inc. v. City of San Antonio, 330 F.3d 288 ( $5^{\text {th }}$ Cir. 2003), cert. denied, 540 U.S. 982 (2003), and opinion clarified, 352 F.3d 938 ( $5^{\text {th }}$ Cir. 2003).

Giovani Carandola, Ltd. v. Fox, 396 F.Supp.2d 630 (M.D.N.C. 2005) 
OFF-SiTE AdULT BUSINESSES - 16

G.M. Enterprises, Inc. v. Town of St. Joseph, WI, 350 F.3d 631 (2003)

H and A Land Corp. v. City of Kennedale, TX, 480 F.3d 336 (5th Cir. 2007).

Northend Cinema, Inc. v. Seattle, 90 Wash.2d 709, 585 P.2d 1153 (1978).

R.V.S., L.L.C. v. City of Rockford, 361 F.3d 402 ( $7^{\text {th }}$ Cir. 2004)

World Wide Video of Washington, Inc. v. City of Spokane, 368 F.3d 1186 (9th Cir. 2004)

Young v. American Mini-Theatres, Inc., 427 U.S.50 (1976).

\section{ENDNOTES}

1 See, e.g., City of Erie v. Pap's A.M., 529 U.S. 277, 319 (2000), where Justice O'Connor stated, "nude dancing still receives First Amendment protection, even if that protection lies only in the "outer ambit' of that Amendment."

2 See. e.g., City of Renton v. Playtime Theaters, Inc., 475 U.S. 41 (1986) where zoning to control the location of adult businesses is upheld.

3 "Common sense" (or "fallible realism") refers to the evolving body of knowledge that is open to non-experts. Scientific knowledge, which is open only to experts, is preceded by common sense. "[A]ll science, and all philosophy, are enlightened common sense" (Popper, 1979: 34; see also, Musgrave, 1993).

4 In City of Los Angeles v. Alameda Books, Inc., 535 U.S. 425 (2002), Justice Souter characterizes this model as "commercially natural, if not universal."

5 Justice O'Connor's opinion criticized the $9^{\text {th }}$ Circuit for imposing too high a bar for cities that seek merely to address the secondary effects of adult businesses. The 9 th Circuit found that the 1977 study did not provide reasonable support for the 1983 amendment because the study focused on the secondary effects associated with a concentration of establishments rather than a concentration of operations within a single establishment. While acknowledging that the city's 1977 study did not assess whether multiple adult businesses operating under one roof were associated with an increase in secondary effects, Justice O'Connor argued that the city could infer that a concentration of operations, no less than a concentration of establishments, would be associated with an increase in negative secondary effects. She then criticized the 9th Circuit for implicitly requiring that the city must not merely provide reasonable support for a theory that justifies its ordinance, but also prove that its theory is the only plausible one.

6 Justice Kennedy contended that this case raised two evidentiary questions for the Court. "First, what proposition does a city need to advance in order to sustain a secondary-effects ordinance? Second, how much evidence is required to support the proposition?" Id. at 425. He argued that the plurality answered only the second question, and while he believed that answer was correct, in his view more attention needed to be paid to the first. The critical inquiry that Justice Kennedy believes the plurality "skips" is "how speech will fare under the city's ordinance." In his view, shared by Justice Souter's dissenting opinion, a "city may not assert that it will reduce secondary effects by reducing speech in the same proportion." In short, "[t]he 
rationale of the ordinance must be that it will suppress secondary-effects-and not by suppressing speech." Id. at 450-51 Applying this first step to the ordinance in this case, Justice Kennedy argued that it would have one of two effects when applied to an establishment operating two adult businesses under one roof: one of the businesses must either move or close. Since the latter of these effects cannot lawfully be the rationale for the ordinance - i.e., the city cannot lawfully seek to reduce the amount of secondary effects merely be reducing the number of adult businesses - the city's rationale must be that affected businesses will relocate rather than close and that the resulting dispersion of businesses will reduce secondary effects but not substantially diminish the number of businesses. Having identified the city's "proposition," Justice Kennedy next asked whether the city had presented sufficient evidence to support that proposition. In line with the plurality, Justice Kennedy argued for significant deference to local government factfinding in making this inquiry. Citing Renton and Young, he contended that cities "must have latitude to experiment at least at the outset, and that very little evidence is required." He also cautioned that "[a]s a general matter, courts should not be in the business of second-guessing the fact-bound empirical assessments of city planners," noting: "The Los Angeles City Council knows the streets of Los Angeles better than we do. It is entitled to rely on that knowledge; and if its inference appears reasonable, we should not say there is no basis for that conclusion." Here, Justice Kennedy found that, for purposes of surviving a motion for summary judgment, the city's proposition is supported by both its 1977 study and "common experience" and that the 1983 ordinance was reasonably likely to reduce secondary effects substantially while reducing the number of adult entertainment businesses very little. Id. at 457.

$7 \quad$ Justice Souter was concerned about what he viewed as the significant risk that courts will approve ordinances that are effectively regulating speech based on government's distaste for the viewpoint being expressed. "Adult speech refers not merely to sexually explicit content, but to speech reflecting a favorable view of being explicit about sex and a favorable view of the practices it depicts; a restriction on adult content is thus also a restriction turning on a particular viewpoint, of which the government may disapprove." For Justice Souter, the risk of viewpoint discrimination may be addressed by imposing on government a requirement that it demonstrate empirically "that the effects exist, that they are caused by the expressive activity subject to the zoning, and that the zoning can be expected either to ameliorate them or to enhance the capacity of the government to combat them (say, by concentrating them in one area), without suppressing the expressive activity itself." Justice Souter claimed that his call for empirical evidence does not impose a Herculean task on government; rather, the harms allegedly caused by adult establishments "can be shown by police reports, crime statistics, and studies of market value, all of which are within a municipality's capacity or available from the distilled experiences of comparable communities." Id. He also noted that the need for "independent proof" can vary with the proposition that needs to be established and thus "zoning can be supported by common experience when there is no reason to question it." Id. at 458-59.

$8 \quad$ But see also R.V.S., L.L.C. v. City of Rockford, 361 F.3d 402 (7 ${ }^{\text {th }}$ Cir. 2004)(finding it unreasonable for city officials to believe that secondary effects were associated with a business where dancers performed wearing fully opaque clothing over the public area, buttocks and breasts when the city had no evidence of secondary effects associated with such businesses and plaintiff's two experts testified no studies demonstrated adverse secondary effects from such businesses; nor did the experts believe such effects could be found). 
9 The NIBRS coding protocol breaks crime events down into component incidents. To illustrate, under the NIBRS protocol, a robbery-homicide event would be coded as two incidents, each with its own characteristics. Incident-based crime rates are ordinarily higher than eventbased crime rates.

10 The UCR coding protocol ignores all but the most serious component incident of an event. Under the UCR protocol, a robbery-homicide event would be coded as a homicide. The per capita crime rates reported in the popular media are ordinarily event-based rates.

11 Paul, Linz, and Shafer (2001: 379) argue that the Los Angeles secondary effects study challenged in Alameda Books found more crime in adult business neighborhoods because the police "were trying harder to find" crime in those neighborhoods. Though not addressing the methodological issue, Justice O'Connor criticized the $9^{\text {th }}$ Circuit for requiring the City of Los Angeles to rule out alternative explanations of its secondary effects evidence. Alameda Books 2000 at $727-728$.

12 Such anecdotes are legitimate secondary effects evidence. See, e.g., World Wide Video of Washington, Inc. v. City of Spokane, 368 F.3d 1186, 1195-96 (9th Cir. 2004) ("Anecdotal evidence and reported experience can be as telling as statistical data and can serve as a legitimate basis for finding negative secondary effects ..."). 